\title{
KORIŠTENJE IRAP METODOLOGIJE PRI SELEKTIRANJU PROMETNIH NESREĆA UZROKOVANIH UMOROM VOZAČA CESTOVNIH VOZILA
}

UDK 656.1.08:613.73

PRIMLJENO: 15.7 .2019$.

PRIHVAĆENO: 8.3.2020.

Ovo djelo je dano na korištenje pod Creative

Commons Attribution 4.0 International License

\begin{abstract}
SAŽETAK: Korištenjem samo klasičnih metoda zasnovanih na izračunu objektivnog statističkog rizika nakon ekspertiza prometnih nesreća vrlo je teško pouzdano izdvojiti one za koje je mogući uzrok umor vozača cestovnih vozila. IRAP metodologija može bitno pomoći u boljem izdvajanju prometnih nesreća za koje je vjerojatni uzrok umor vozača, jer se iRAP metodologijom može brzo i objektivno procijeniti statička sigurnost prometne infrastrukture, a onda i isključiti kao mogući uzrok. Prema dinamičkom otvorenom Fullerovom TCl modelu "zahtjev zadaće-sposobnost vozača", vozači dominantno određuju željenu razinu težine zadaće tijekom vožnje odabirom brzine, što u slučaju odabira nedopuštene brzine ili brzine neprilagođene uvjetima na cesti između ostaloga može ovisiti i o tome je li vozač umoran ili ne. Na primjeru šest prometnih nesreća na autocestama u Republici Hrvatskoj, izdvojenih statističkom obradom prema karakterističnim kriterijima iz recentne znanstvene literature, pokazat će se kako se primjenom iRAP metodologije odrednice prometne infrastrukture iz skupine čimbenika "prometni okoliš" mogu potpuno isključiti kao uzrok prometne nesreće. Što točnije izdvajanje prometnih nesreća cestovnih vozila za koje je mogući uzrok umor pomoći će kolegama istraživačima iz ostalih znanstvenih područja istražiti karakteristične čimbenike prometnih nesreća povezanih s umorom, a zbog predlaganja mjera za smanjivanje utjecaja umora na izvedbu vozača.
\end{abstract}

Ključne riječi: umor, prometne nesreće, cestovna vozila, težina zadaće, izvedba, sigurnost

\section{UVOD}

$\cup$ ovome radu prezentirane selekcijske analize provedene su s ciljem iznalaženja karakterističnih selekcijskih čimbenika prometnih nesreća (PN), a zbog što preciznijeg izdvajanja PN za koje je vjerojatni uzrok umor vozača, u čemu procjena statičke sigurnosti prometne infrastrukture korištenjem iRAP metodologije može bitno pomoći.

Prema dinamičkom otvorenom Fullerovom $\mathrm{TCl}$ modelu "zahtjev zadaće-sposobnost vozača", vozači dominantno utječu na željenu razinu težine zadaće tijekom vožnje odabirom brzine

*Dr. sc. Davor Sumpor, izv. prof., (dsumpor@fpz.hr), doc. dr. sc. Marko Ševrović, (msevrovic@fpz.hr), Sandro Tokić, mag. ing. traff., (stokic@fpz.hr),Bojan Jovanović, mag. ing. traff., (bjovanovic@fpz.hr), Sveučilište u Zagrebu, Fakultet prometnih znanosti, Vukelićeva 4, 10000 Zagreb.
(Fuller, 2005.). Međutim, autori ovoga rada smatraju da degradacija izvedbe zbog odabira nedopuštene brzine ili brzine neprilagođene uvjetima na cesti između ostaloga može ovisiti i o tome koliko je vozač umoran, na što upućuje okolnost da u istraživanim PN nije bilo reduciranja brzine u skladu s prometnom situacijom neposredno prije nastanka PN, što sugerira situaciju da je vozač prouzročio PN zbog umora.

Rumar je 1982. godine sumirao i komparirao dvije dugogodišnje i nezavisne studije cestovnih istraživačkih laboratorija u Velikoj Britaniji i SAD-u (Rumar, 1982.) s visoko podudarnim rezultatima prikazanim na slici 1, a na temelju rezultata koje su dobile skupine eksperata nakon dubinskih studija oštećenih cestovnih vozila, mjesta nesreća i sudionika poslije PN s ciljem utvrđivanja postotnih udjela u PN za tri osnovne skupine čimbeni- 
ka sustava čovjek - prometno sredstvo - prometni okoliš. Gornji postotni udjeli (u kružnim sastavnicama slike) i lijevi postotni udjeli (u pravokutnim sastavnicama slike) su postotni udjeli iz britanske studije, a donji postotni udjeli (u kružnim sastavnicama slike) i desni postotni udjeli (u pravokutnim sastavnicama slike) su postotni udjeli iz američke studije, a za pojedinačno, dvostruko i trostruko sudjelovanje sve tri skupine čimbenika u PN cestovnih vozila (samostalni udjeli pojedine skupine čimbenika u nastanku PN te interakcijski udjeli dvije, ili sve tri skupine čimbenika). U pravokutnim sastavnicama slike s nazivom skupine čimbenika upisan je ukupni skupni postotak za svaku skupinu čimbenika sa svim preklapanjima.

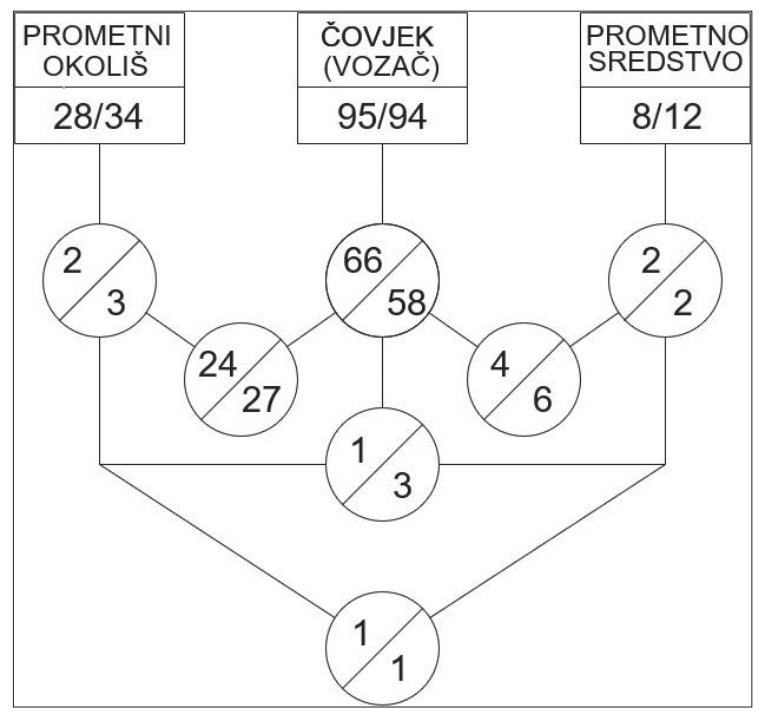

Slika 1. Udio čimbenika iz skupine "ljudskoga faktora" kod vozača cestovnih vozila na temelju ekspertiza PN

Figure 1. Ratio of the factors in the 'human factors' group in drivers based on the study of traffic accidents

Prema slici 1. (Rumar, 1982.) očito je da skupina čimbenika "ljudskoga faktora", bilo pojedinačno, bilo u interakciji s ostalim čimbenicima, ima dominantan utjecaj, tj. sudjeluje sa $95 \%$ i $94 \%$. Pojedinačno sudjelovanje skupine „Ijudskoga faktora" u PN dostiže oko dvije trećine ukupnih slučajeva (66 \% u britanskoj i 58 \% u američkoj studiji). Utjecaj skupine čimbenika „ljudskoga faktora” sa svim preklapanjima dominira nad ostalim skupinama čimbenika („prometno sredstvo" i „prometni okoliš”) pa su oni manje vidljivi. Međutim, skupno sudjelovanje skupine čimbenika „prometni okoliš” dostiže čak $28 \%$ u britanskoj, te $34 \%$ u američkoj studiji.
Autori smatraju da će se udjel skupine čimbenika "ljudskoga faktora", bilo pojedinačno, bilo u interakciji s ostalim skupinama čimbenika, u budućnosti smanjivati zbog sve veće primjene naprednih sustava za pomoć vozačima, ali i da će ostati dominantan tako dugo dok većina vozača upravlja svojim vozilima.

Zbog dominantnog utjecaja skupine čimbenika "ljudskoga faktora" na nastanak PN, kako pojedinačno tako i sa svim preklapanjima, iznimno je bitno koji su karakteristični čimbenici takvih PN za koje je moguće da su prouzrokovane umorom vozača, a radi mjerenja umora u simuliranim prometnim situacijama na simulatorima cestovnog prometa, s ciljem razvoja sustava za pomoć vozačima koji će detektirati umor vozača.

Općenito prihvaćene vrste umora su (Kroemer, Grandjean, 2000.):

- Mišićni umor zbog smanjenja umora nekog mišića, manifestira se smanjenjem snage (kontrakcija na podražaj je sve manja) i sve sporijim pokretima;

- Umor očiju, nastaje preopterećenjem vidnog sustava;

- Opći tjelesni umor, posljedica preopterećenja organizma radom;

- Mentalni umor, nastaje pri mentalnom ili intelektualnom radu;

- Živčani umor, izaziva ga preopterećenje jednog dijela psihomotoričkog sustava preciznim, ali često repetitivnim radom;

- Kronični umor, nastaje akumulacijom dugoročnih efekata;

- Cirkadijurni umor, nastaje zbog poremećaja cirkadijurnih ritmova i obično se javlja kao posljedica smjenskog rada koji sadrži i rad noću.

Metode mjerenja umora i indikatori veličine umora mogu se općenito svrstati u šest skupina (Kroemer, Grandjean, 2000.):

- kvaliteta i kvantiteta radnog učinka,

- subjektivni osjećaj umora,

- elektrofiziološka mjerenja (EEG i EKG),

- facijalna ekspresija,

- bihevioralni testovi: vrijeme reakcije PRT mjereno testovima papir olovka, mjere- 
njima na reakciometaru ili simulatoru te struktura i broj krivih reakcija (engl. errors),

- mentalni testovi.

Poznate metode mjerenja umora imaju ozbiljnih nedostataka ako se primjenjuju pojedinačno. Do danas nema direktnog načina mjerenja razine umora vozača cestovnih vozila u realnim uvjetima jer ne postoji objektivna mjera umora vozača cestovnih vozila u realnim okolnostima (Kroemer, Grandjean, 2000.).

Navedena mjerenja često se rade prije, za vrijeme i poslije radnog zadatka, a o veličini umora zaključuje se iz dobivenih rezultata. $U$ pravilu rezultat ima samo relativno značenje, jer daje vrijednost koja se uspoređuje s vrijednošću kad je ispitanik u stanju mirovanja, ili s nekom "kontrolnom" osobom koja nije u stresnoj situaciji. Dakle, nema načina da se umor direktno mjeri u nekim apsolutnim jedinicama (Kroemer, Grandjean, 2000.).

Studija Hornea i Reynera (1999.) pokazala je kako je najmanje 15 - $20 \%$ svih PN povezivo s umorom i pospanošću. Vozači mlađi od 30 godina su pod većim rizikom od vožnje u pospanom stanju iz razloga što su osjetljiviji na manjak sna prije početka vožnje na dugim dionicama na autocestama (AC) koji je pojedincu potreban kako bi se osjećao budnim i alarmiranim (Prybil et al., 2015.). Također, jedan od mogućih razloga je ponašanje mladih vozača koji često znaju precijeniti svoju vozačku sposobnost i time sami predstavljaju rizik za ostale sudionike u prometu (Lela et al., 2012., Julie, Ralston, 2009.), ali takav rizičniji stil prometnog ponašanja mlađih vozača treba u analizama pokušati razdvojiti od većeg rizika od vožnje u pospanom stanju kod vozača mlađih od 30 godina. U studiji Connora et al. (2001.a) demonstrirano je da pospanost povećava rizik od PN za 8,2 puta te da je količina sna do 5 sati tijekom 24 sata prije nastanka PN i vožnja između 2 i 5 ujutro glavni rizični čimbenik uzročnika PN (Connor et al., 2001.b).

U studiji slučaja autora Halvani et al. (2019.) provedenoj na 716 profesionalnih vozača iz Irana metodom upitnika i intervjuiranja cilj je bio istražiti povezanost pospanosti i nastanka PN. Profesionalni vozači bili su podijeljeni u dvije skupine. Eksperimentalnu skupinu (vozači koji su u posljednje 3 godine sudjelovali u najmanje jednoj PN) činilo je 254 vozača, dok je ostatak činio kontrolnu skupinu (profesionalni vozači koji nikad nisu sudjelovali u PN). Rezultati su pokazali da su pospanost i umor najveći prijavljeni uzrok PN s udjelom od $35 \%$, dok je na drugom mjestu bila nepažnja i propusti drugih vozača s udjelom od $18,1 \%$.

U studiji iz 2011. godine (Rossi et al., 2011.) u svrhu mjerenja pasivnog umora provedeno je istraživanje na studentima ispitanicima u simulatoru vožnje za cestovni promet. Parametri poput frekvencije i iznosa zaokreta volana te lateralne pozicije vozila mjereni su u simulatoru, te korišteni za statističku obradu kako bi se odredio negativan utjecaj čimbenika koji najviše utječu na pojavu pasivnog umora. Rezultati istraživanja pokazali su kako najveći utjecaj na umor ima dužina izvedbe zadatka, zatim doba dana (utjecaj cirkadijurnih ritmova), te potom monotoni okoliš. Također je dokazano da je izvedba vozača cestovnih vozila u simulatoru bila lošija u slučaju kada su ispitanici vozili monotoni scenarij, nego dinamički scenarij.

$\mathrm{PN}$ povezive $\mathrm{s}$ umorom mogu se identificirati pomoću sljedećih najvažnijih kriterija pojave pasivnog umora selektiranih na ispitanicima studentima u simulatoru vožnje za cestovni promet (Rossi et al., 2011.), ili kriterija dobivenih analizama PN povezivih s umorom u Ujedinjenom Kraljevstvu (UK) i slično u Sjedinjenim Američkim Državama (SAD); (Maycock, 1997., Lyznicki et al., 1998., van der Hulst et al., 2001.):

- Dužina izvedbe zadatka vozača (pasivni umor, simulator vožnje).

- Monotoni okoliš prometnice (pasivni umor, simulator vožnje).

- Vozilo je sletilo s ceste (UK).

- Ne postoje tragovi klizanja i(li) kočenja vozila (UK).

- Vozač je mogao vidjeti mjesto izlijetanja ili objekt u koji je udario prije sudara (UK).

- Svjedoci PN prijavili su da je vozač izgubio kontrolu nad vozilom prije sudara (UK).

- PN koje se dešavaju kasno u noć, rano ujutro ili u poslijepodnevnim satima (SAD).

- Doba dana zbog utjecaja cirkadijurnih ritmova (pasivni umor, simulator vožnje). 
- Posljedice PN su najčešće teške ozljede ili smrtno stradali (SAD).

- Jedno vozilo izletjelo je s ceste (SAD).

- Sudar se dogodio na cesti s visokim ograničenjem brzine (SAD).

- Vozač ne pokušava izbjeći sudar (SAD).

- Vozač je sam u vozilu (SAD).

Ako se razmatra vrlo česta reakcija vozača i vrijeme kočenja BT (engl. brake time), moguće su dvije neprimjerene reakcije vozača za koje između ostaloga jedan od mogućih uzroka može biti i umor vozača: vozač cestovnog vozila prekasno je počeo pritiskati kočnicu (vremenski neprimjerena reakcija koja je najsličnija definiciji propusta) ili je pedalu kočnice stisnuo premalom silom (intenzitetom neprimjerena reakcija vozača koja je najsličnija definiciji omaške). Već nekoliko desetaka godina u realitetu prometuju osobna vozila koja imaju ugrađene različite napredne sustave za pomoć vozaču, između ostaloga i za anuliranje te dvije vremenski i intenzitetom neprimjerene reakcije vozača.

U Tablici 1. prikazano je šest razina automatizacije prema klasifikaciji Društva automobilskih inženjera SAE (engl. Society of Automotive Engineers) od nulte razine koja podrazumijeva vozila bez ikakve automatizacije, pa sve do zadnje, pete razine, koja podrazumijeva potpunu automatizaciju za automobile poznate pod kolokvijalnim nazivom autonomno vozilo (https://www.sae.org/ misc/pdfs/automated_driving.pdf).

U skladu s navedenim, u daljnjem tekstu ovog rada umjesto pojma potpune automatizacije (5. razina) koristit će se pojam autonomno vozilo.

Međutim, danas u cestovnom prometu u Europi i svijetu istovremeno prometuju osobna vozila iz različitih razina automatizacije prikazanih u Tablici 1 , a trenutačno se na više mjesta u svijetu testiraju prototipovi autonomnih vozila. Tako je npr. moguća situacija gdje autonomno vozilo ne može izbjeći sudar s osobnim vozilom 0. razine automatizacije, a zbog neprimjerene reakcije vozača istog, iako osobno vozilo 0. razine može eventualno biti opremljeno sustavom za upozoravanje vozača.

$U$ radu će se na primjeru nekoliko odabranih karakterističnih PN na AC u RH između PN selektiranih deskriptivnom statistikom u skladu s karakterističnim relevantnim selekcijskim kriterijima i spoznajama iz recentne znanstvene i stručne literature istraživanjem provjeriti hipoteza kako se primjenom iRAP metodologije čimbenici prometne infrastrukture iz skupine čimbenika „prometni okoliš" mogu isključiti kao uzrok nastanka odabranih PN.

Tablica 1. Šest razina automatizacije vožnje prema SAE

Table 1. Six automated driving levels according to SAE

\begin{tabular}{|c|c|l|c|}
\hline $\begin{array}{c}\text { Razina } \\
\text { automatizacije } \\
\text { vožnje }\end{array}$ & $\begin{array}{c}\text { Naziv } \\
\text { razine }\end{array}$ & $\begin{array}{c}\text { Opis razine } \\
\text { automatizacije }\end{array}$ & $\begin{array}{l}\text { Vozač u potpunosti upravlja vozilom, čak i onda kada sustav za pomoć vozaču oglasi } \\
\text { upozorenje. }\end{array}$ \\
\hline 0 & $\begin{array}{c}\text { Sustavi pomoći } \\
\text { vozaču }\end{array}$ & $\begin{array}{l}\text { Vozač upravlja vozilom uz pomoć sustava za kontrolu brzine (ubrzavanje/usporavanje) ili } \\
\text { sustava za održavanje lateralnog položaja vozila koji se koristi informacijama o prometnom } \\
\text { okruženju. }\end{array}$ \\
\hline 2 & $\begin{array}{c}\text { Parcijalna } \\
\text { automatizacija }\end{array}$ & $\begin{array}{l}\text { Vozač upravlja vozilom uz pomoć sustava za kontrolu brzine (ubrzavanje/usporavanje) i } \\
\text { sustava za održavanje lateralnog položaja vozila koji se koristi informacijama o prometnom } \\
\text { okruženju. }\end{array}$ \\
\hline 3 & $\begin{array}{c}\text { Uvjetna } \\
\text { automatizacija }\end{array}$ & $\begin{array}{l}\text { Automatizirani sustav vožnje koji upravlja svim aspektima dinamičkog zadatka vožnje uz } \\
\text { očekivanje da će vozač intervenirati na zahtjev sustava. }\end{array}$ \\
\hline 5 & $\begin{array}{c}\text { Visoka } \\
\text { automatizacija }\end{array}$ & $\begin{array}{l}\text { Automatizirani sustav vožnje koji upravlja svim aspektima dinamičkog zadatka vožnje čak i } \\
\text { onda kada vozač pravovremeno ne reagira na zahtjev sustava za intervenciju. }\end{array}$ \\
\hline $\begin{array}{c}\text { Potpuna } \\
\text { automatizacija - } \\
\text { AUTONOMNO } \\
\text { VOZILO }\end{array}$ & $\begin{array}{l}\text { Automatizirani sustav vožnje koji upravlja svim aspektima dinamičkog zadatka vožnje na } \\
\text { svim vrstama prometnica i u svim vremenskim uvjetima kojim može upravljati vozač. }\end{array}$ \\
\hline
\end{tabular}




\section{METODE ISTRAŽIVANJA}

Za potrebe ovog istraživanja iz baza svih $\mathrm{PN}$ MUP-a RH na svim cestama i za cijelu RH za godine od 2013. do 2017., za koju su zbirni rezultati prikazani u Tablici 2, prvo je kreirana posebna baza PN samo s poginulim i teško ozlijeđenim sudionicima na $\mathrm{AC}$ u RH za svaku godinu.

Tablica 2. Broj PN po vrsti PN u godinama od 2013. do 2017.

Table 2. Number of road accidents by type, 20132017

\begin{tabular}{||c|c|c|c|c|c||}
\hline PN & 2013. & 2014. & 2015. & 2016. & 2017. \\
\hline $\begin{array}{c}\text { S poginulim } \\
\text { osobama }\end{array}$ & 328 & 284 & 317 & 279 & 307 \\
\hline $\begin{array}{c}\text { S teško } \\
\text { ozlijeđenim } \\
\text { osobama }\end{array}$ & 2.831 & 2.675 & 2.822 & 2.747 & 2.776 \\
\hline $\begin{array}{c}\text { Samo s } \\
\text { materijalnom } \\
\text { štetom }\end{array}$ & 22.796 & 20.825 & 21.533 & 21.978 & 23.422 \\
\hline$\Sigma$ & 34.021 & 31.432 & 32.571 & 32.757 & 34.366 \\
\hline \hline
\end{tabular}

Izvor: obrađeni podaci MUP-a RH

Nakon toga je iz iste baze po više karakterističnih filtara u skladu sa spoznajama iz znanstvene i stručne literature metodama deskriptivne statistike selektirano više $\mathrm{PN}$, iz kojih je odabrano šest karakterističnih PN, čimbenici kojih su zatim dubinski analizirani. Između ostaloga, primjenom iRAP metodologije istraživano mogu li se čimbenici prometne infrastrukture iz skupine čimbenika „prometni okoliš̌" isključiti kao mogući uzrok nastanka šest karakterističnih PN. Između cijelog niza ostalih karakterističnih čimbenika koji upućuju na umor kao mogući uzrok nastanka PN posebna pozornost posvećena je okolnosti nepostojanja reduciranja brzine u skladu s prometnom situacijom neposredno prije nastanka PN, što sugerira situaciju da je vozač prouzročio PN zbog umora. Da je umor mogući uzrok nastanka PN dodatno je evaluirano i pomoću osobne procjene o umoru kao mogućem uzroku PN od strane iskusnog suradnika iz MUP-a RH na temelju uvida u kompletnu dokumentaciju o PN.

Šest u radu analiziranih PN povezivih s umorom vozača selektitrano je ciljano iz baze PN s poginulim i teško ozlijeđenim sudionicima koja je kvalitetnije ažurirana i potpunija (niti za jednu varijablu u takvoj bazi ne nedostaje više od $5 \%$ vrijednosti) u odnosu na baze PN s lakše ozlijeđenim osobama ili materijalnom štetom, a zbog ozbiljnijeg pristupa djelatnika MUP-a RH tijekom očevida i tijekom unošenja podataka iz pisanih dokumenata u interne baze MUP-a o PN s poginulim i teško ozlijeđenim sudionicima na AC.

Potrebno je napomenuti da autori ovoga istraživanja nisu imali za konačni cilj iz baza PN s poginulim i teško ozlijeđenim sudionicima na AC u RH odrediti postotni udjel svih PN za koje je umor mogući uzrok nastanka PN, već selektirati i dubinski analizirati u skladu s karakterističnim relevantnim kriterijima iz literature i uz pomoć iRAP metodologije samo nekoliko karakterističnih $P N$ na $A C$ za koje je umor najvjerojatniji uzrok nastanka PN.

\section{IRAP METODOLOGIJA ZA PROCJENU STATISTIČKOG RIZIKA CESTOVNE INFRASTRUKTURE}

IRAP (engl. International Road Assessment Program) predstavlja program međunarodne procjene cesta u svrhu promicanja sigurnije cestovne infrastrukture s ciljem spašavanja života i sprečavanja ozbiljnijih ozljeda sudionika u cestovnom prometu. Od sveukupno četiri razvijena protokola za procjenu i poboljšanje sigurnosti prometne infrastrukture, ocjena zvjezdicama (engl. star rating) korištena je za statičku procjenu rizika cestovne infrastrukture. Ocjena zvjezdicama SRS (engl. Star rating score) predstavlja mjeru rizika za individualne korisnike cestovne prometne infrastrukture koja je "ugrađena" u cestu. Temelji se na podacima o snimljenom georeferenciranom videozapisu cestovne infrastrukture i daje jednostavnu i objektivnu mjeru razine sigurnosti za sve sudionike u prometu.

Protokol iRAP ocjenjivanje zvjezdicama zapoČinje snimanjem georeferenciranog videozapisa ceste za slučaj ocjenjivanja postojeće prometne infrastrukture ili se za slučaj nove planirane cestovne infrastrukture atributi (elementi prometne infrastrukture) bilježe na temelju dostupne projektne dokumentacije, nakon čega slijedi proces kodiranja ceste u specijaliziranom programskom 
alatu uz pomoć kojeg se dodjeljuju atributi čiji se pojedini rizik temelji na rezultatima međunarodnih istraživanja i ekspertiza PN u svijetu.

Zatim se pomoću web sučelja "ViDA", dostupnog na web stranici https://vida.irap.org/hr/ home, podaci obrađuju i izlazni parametri su SRS ocjene razine rizika (zvjezdice) za sve sudionike te predloženi plan provedbe mjera poboljšanja cestovne prometne infrastrukture koji sadrži opis rizika i čimbenika cestovne infrastrukture koji pridonose riziku, procjenu troškova i efektivnosti provedbe pojedinih mjera sanacije, prilagodbu mjera sanacije, procjenu mogućeg smanjenja broja poginulih i teško ozlijeđenih osoba, kao i troškova i koristi u slučaju implementacije predloženih mjera sanacije.

IRAP metodologija koristi se multiplikativnim matematičkim modelom prikazanim na slici 2 kojim se utvrđuje u kojoj mjeri cestovna infrastruktura pridonosi riziku od teških tjelesnih ozljeda ili smrti u slučaju nastanka PN (https://www.irap. org/how-we-can-helph).

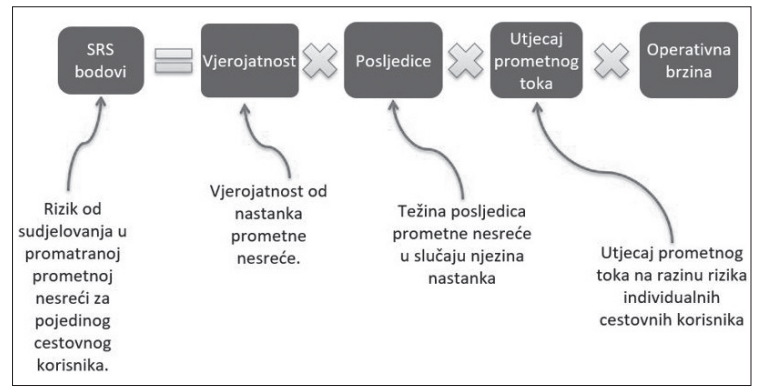

Slika 2. Jednadžba za dobivanje ocjene zvjezdicama

Figure 2. Equation for getting a star mark

Glavne skupine elemenata prometne infrastrukture za koje se radi procjena sigurnosti iRAP metodologijom su:

- Okolina ceste (engl. roadside);

- Karakteristike ceste (engl. mid block);

- Raskrižja (engl. intersections);
- Prometni tok (engl. traffic flow);

- Objekti za ranjive sudionike u prometu i namjena zemljišta (engl. VRU facilities and land use);

- Brzine kretanja vozila (engl. speeds); (https://vida.irap.org/en-gb/home).

\section{RELEVANTNI ČIMBENICI PROMETNIH NESREĆA NA AUTOCESTAMA POVEZIVI S UMOROM VOZAČA}

Povećani statistički rizik za nastanak PN zbog umora vozača cestovnih vozila je u razdobljima od 4 do 6 sati ujutro, od ponoći do 2 sata ujutro, te popodne između 2 i 4 sata (Maycock, 1997.).

U Tablici 3 prikazan je broj PN koje su se desile noću, u sumrak i u svitanje od 2013. do 2017. godine, a koje su selektirane prema filtru Vrste PN u skladu s karakterističnim kriterijima za selekciju iz recentne literature (Maycock, 1997., Lyznicki et al., 1998., van der Hulst et al., 2001.), a sugeriraju situaciju da je vozač vjerojatno prouzročio PN zbog umora, jer nije bilo reduciranja brzine u skladu s prometnom situacijom prije njezina nastanka. Analize prezentirane u tablicama 4, 5, 6, 7 i 8 napravljene su samo za poginule i teško ozlijeđene vozače cestovnih vozila, a za godine od 2013. do 2017., i to samo za AC jer su to najsigurnije cestovne prometnice $\mathrm{u} \mathrm{RH}$ redovito ocjenjivane za statičku sigurnost visokim ocjenama pomoću iRAP metodologije. $U$ tablicama 4, 5, 6, 7 i 8 arapski broj u obloj zagradi ispred čimbenika PN je interna šifra MUP-a RH za tu vrstu $\mathrm{PN}$, a arapski broj bez zagrade iza čimbenika PN ili u pojedinim stupcima po pojedinim godinama je broj PN za tu vrstu PN na AC u RH. Rangiranje pojedinih čimbenika $\mathrm{PN}$ u tablicama ima relativni značaj, jer su međusobno rangirani po broju PN u kojima se pojavljuju (arapski broj bez zagrade iza čimbenika PN). 
Iz baza za PN u RH u godinama od 2013. do 2017. (samo za poginule i teško ozlijeđene vozače cestovnih vozila na $\mathrm{AC} u \mathrm{RH}$ ) relativno su jedan o odnosu na drugog rangirani čimbenici statističkog rizika (na način da je u tablici za pojedinu godinu u pojedinoj skupini čimbenika više rangiran onaj čimbenik koji se pojavljuje u više PN).

Takvi potencijalni statistički čimbenici povećanog rizika za nastanak $\mathrm{PN}$ povezivih s umorom prezentirani su u Tablici 4 (za godinu 2017.), Tablici 5 (za godinu 2016.), Tablici 6 (za godinu 2015.), Tablici 7 (za godinu 2014.) i Tablici 8 (za godinu 2013.), a po selekcijskim skupinama čimbenika odabranih od autora kako slijedi:

- Okolnosti koje su prethodile PN;

- Karakteristike ceste;

- Stanje kolničke površine;

- Vidljivost.

Tablica 3. Relevantni čimbenici PN noću, u sumrak i svitanje koji ukazuju na umor kao mogući uzrok nastanka PN

Table 3. Relevant factors for road accidents at night, at dusk and at dawn indicating fatigue as the possible cause of accident

\begin{tabular}{||l|c|c|c|c|c||}
\hline \multirow{2}{*}{\multicolumn{1}{|c|}{ Vrste PN }} & \multicolumn{5}{|c|}{ Broj PN na AC u RH po godinama za filtar Vrste PN } \\
\cline { 2 - 6 } & $\mathbf{2 0 1 3}$ & $\mathbf{2 0 1 4}$ & $\mathbf{2 0 1 5 .}$ & $\mathbf{2 0 1 6 .}$ & $\mathbf{2 0 1 7 .}$ \\
\hline (8) Slijetanje s ceste & 6 & 6 & 3 & 3 & 4 \\
\hline (15) Udar vozila u objekt kraj ceste & 1 & 0 & 0 & 1 & 2 \\
\hline (16) Udar vozila u objekt na cesti & 0 & 0 & 0 & 3 & 1 \\
\hline \hline
\end{tabular}

Izvor: obrađeni podaci MUP-a RH

Tablica 4. Čimbenici PN s teško ozlijeđenima i poginulima na AC u RH za 2017. godinu bez filtra Vrste PN

Table 4. Factors in road accidents with badly injured and dead on motorways in Croatia in 2017, without the accident type filter

\begin{tabular}{||l|c|c|c||}
\hline \multicolumn{1}{|c|}{ Okolnosti koje su prethodile PN } & Karakteristike ceste & Stanje kolničke površine & Vidljivost \\
\hline (19) - ostale greške vozača / 6 & (18) - ravni cestovni potez / 11 & (1) - suh-čist / 8 & (2)-noć / 12 \\
\hline (2) - brzina neprimjerena uvjetima / 5 & $(17)$ - zavoj / 2 & (3) - mokar / 5 & sumrak / 1 \\
\hline (20) - nepropisno kretanje vozila na kolniku / 1 & & & \\
\hline (3) - vožnja na nedovoljnoj udaljenosti / 1 & & & \\
\hline (12) - nepropisno prestrojavanje / 0 & & & \\
\hline (1) - nepropisna brnut / 0 & & \\
\hline
\end{tabular}

Izvor: obrađeni podaci MUP-a RH

Tablica 5. Čimbenici PN s teško ozlijeđenima i poginulima na AC u RH za 2016. godinu bez filtra Vrste PN

Table 5. Factors in road accidents with badly injured and dead on motorways in Croatia in 2016, without the accident type filter

\begin{tabular}{||l|c|c|c||}
\hline \multicolumn{1}{|c|}{ Okolnosti koje su prethodile PN } & Karakteristike ceste & Stanje kolničke površine & Vidljivost \\
\hline (2) - brzina neprimjerena uvjetima / 8 & (18) - ravni cestovni potez / 10 & (1) - suh-čist / 10 & $(2)-$ noć / 9 \\
\hline (20) - nepropisno kretanje vozila na kolniku / & $(17)$ - zavoj / 7 & (3) - mokar / 7 & $(4)-$ svitanje / 4 \\
\hline (19) - ostale greške vozača / 3 & & (5) - snijeg - razgrnut / 0 & (3)-sumrak / 0 \\
\hline (3) - vožnja na nedovoljnoj udaljenosti / & & & \\
\hline (12) - nepropisno prestrojavanje / 0 & & & \\
\hline (1) - nepropisna brzina / 0 & & & \\
\hline
\end{tabular}

Izvor: obrađeni podaci MUP-a RH 
Tablica 6. Čimbenici PN s teško ozlijeđenima i poginulima na AC u RH za 2015. godinu bez filtra Vrste PN

Table 6. Factors in road accidents with badly injured and dead on motorways in Croatia in 2015, without the accident type filter

\begin{tabular}{|c|c|c|c|}
\hline Okolnosti koje su prethodile PN & Karakteristike ceste & Stanje kolničke površine & Vidljivost \\
\hline (2) - brzina neprimjerena uvjetima / 3 & (18) - ravni cestovni potez / 6 & (3) - mokar / 4 & (2) - noć / 6 \\
\hline (19) - ostale greške vozača / 2 & (17) - zavoj / 1 & (1) - suh-čist / 3 & (4) - svitanje / 1 \\
\hline (1) - nepropisna brzina / 1 & & (5) - snijeg - razgrnut / 0 & (3) - sumrak / 0 \\
\hline \multicolumn{4}{|l|}{ (3) - vožnja na nedovoljnoj udaljenosti / 1} \\
\hline \multicolumn{4}{|l|}{ (12) - nepropisno prestrojavanje / 0} \\
\hline (20) - nepropisno kretanje vozila na kolniku / 0 & & & \\
\hline
\end{tabular}

Izvor: obrađeni podaci MUP-a RH

Tablica 7. Čimbenici PN s teško ozlijeđenima i poginulima na AC u RH za 2014. godinu bez filtra Vrste PN

Table 7. Factors in road accidents with badly injured and dead on motorways in Croatia in 2014, without the accident type filter

\begin{tabular}{|c|c|c|c|}
\hline Okolnosti koje su prethodile PN & Karakteristike ceste & Stanje kolničke površine & Vidljivost \\
\hline (2) - brzina neprimjerena uvjetima / 3 & (18) - ravni cestovni potez / 6 & (1) - suh-čist / 6 & (2) - noć / 8 \\
\hline (20) - nepropisno kretanje vozila na kolniku / 2 & (17) - zavoj / 2 & (3) - mokar / 2 & (3) - sumrak / 0 \\
\hline (19) - ostale greške vozača / 2 & & (5) - snijeg - razgrnut / 0 & (4) - svitanje / 0 \\
\hline \multicolumn{4}{|l|}{ (3) - vožnja na nedovoljnoj udaljenosti / 1} \\
\hline \multicolumn{4}{|l|}{ (12) - nepropisno prestrojavanje / 0} \\
\hline (1) - nepropisna brzina / 0 & & & \\
\hline
\end{tabular}

Izvor: obrađeni podaci MUP-a RH

Tablica 8. Čimbenici PN s teško ozlijeđenima i poginulima na AC u RH za 2013. godinu bez filtra Vrste PN

Table 8. Factors in road accidents with badly injured and dead on motorways in Croatia in 2013, without the accident type filter

\begin{tabular}{|c|c|c|c|}
\hline Okolnosti koje su prethodile PN & Karakteristike ceste & Stanje kolničke površine & Vidljivost \\
\hline (20) - nepropisno kretanje vozila na kolniku / 3 & (18) - ravni cestovni potez / 6 & (1) - suh-čist / 6 & (2) - noć / 7 \\
\hline (2) - brzina neprimjerena uvjetima / 2 & (17) - zavoj / 2 & (3) - mokar / 2 & (4) - svitanje / 1 \\
\hline (19) - ostale greške vozača / 2 & & (5) - snijeg - razgrnut / 0 & (3) - sumrak / 0 \\
\hline \multicolumn{4}{|l|}{ (1) - nepropisna brzina / 1} \\
\hline \multicolumn{4}{|l|}{ (3) - vožnja na nedovoljnoj udaljenosti / 0} \\
\hline (12) - nepropisno prestrojavanje / 0 & & & \\
\hline
\end{tabular}

Izvor: obrađeni podaci MUP-a RH 
Između PN prikazanih u Tablici 4 (za godinu 2017.), Tablici 5 (za godinu 2016.), Tablici 6 (za godinu 2015.), Tablici 7 (za godinu 2014.) i Tablici 8 (za godinu 2013.) dodatno su analizirane PN za koje je vjerojatno da sadrže ponavljajuće okolnosti koje je moguće povezati s umorom vozača cestovnih vozila. Tako npr. u 3 od 5 istraživanih godina dominantna okolnost (po broju PN) koja je prethodila PN je brzina neprimjerena uvjetima (nakon toga manji broj PN za okolnosti ostale greške vozača i nepropisno kretanje vozila na kolniku). Dominantna karakteristika ceste je u svih 5 istraživanih godina ravni cestovni potez (nakon toga manji broj PN u zavojima). Dominantno stanje kolničke površine je suh-čist kolnik u 4 od 5 istraživanih godina (nakon toga manji broj PN za mokar kolnik) i pretežito dominantan čimbenik vidljivosti je noć (gotovo da i nema PN da su se desile u svitanje ili sumrak).

U skladu s rezultatima analiza prezentiranim u tablicama u ovome poglavlju, a uz uvažavanje selekcijskih kriterija iz recentne literature (Maycock, 1997., Lyznicki et al., 1998., van der Hulst et al., 2001., Rossi et al., 2011.) u sljedećem poglavlju detaljno je analizirano šest odabranih karakterističnih PN na AC u RH za koje je visoko vjerojatno da ih je prouzročio umor vozača.

\section{ANALIZA STATIČKE SIGURNOSTI LOKACIJA PROMETNIH NESREĆA NA AUTOCESTAMA KORIŠTENJEM IRAP METODOLOGIJE}

Zbog kontinuiranog i u zadnje vrijeme intenzivnog povećanja udjela $\mathrm{PN}$ povezanih s umorom ili pospanošću vozača u njihovom ukupnom broju, a zbog nemogućnosti jednostavnog mjerenja razine umora tijekom upravljanja vozilom na lokaciji PN, iznimno važno je moći identificirati i odabrati specifične PN za koje je visoko vjerojatno da ih je uzrokovao umor na temelju njihovih selekcijskih čimbenika iz recentne literature, ali uz istovremeno uklanjanje čimbenika cestovne infrastrukture iz skupine čimbenika prometnog okoliša kao uzroka PN.
U ovom poglavlju bit će prikazane fotografije lokacija PN vrlo monotonog okoliša koje su se desile noću na ravnim dionicama $\mathrm{AC}$ ( $3 \mathrm{PN}$ ) te $\mathrm{u}$ zavojima na AC (3 PN), za koje se s visokom sigurnošću može konstatirati da im je glavni uzrok bio umor vozača (slike 2-7); (https://maps.google. hr/). Da je umor glavni uzrok PN prezentiranih u ovome poglavlju, dodatno je potvrđeno pripadnošću analiziranih PN karakterističnim skupinama čimbenika selektiranih u ovome poglavlju, procjenom statičke sigurnosti prometnice dobivene iRAP metodologijom koja isključuje nesigurnost prometne infrastrukture kao uzrok PN te na kraju procjenom iskusnog djelatnika MUP-a RH na osnovi uvida u svu internu dokumentaciju MUP-a $\mathrm{RH}$ za istraživane $\mathrm{PN}$.

Za finalni odabir šest u ovome radu analiziranih PN na AC u RH za koje je visoko vjerojatno da ih je uzrokovao umor korišteni su sljedeći selekcijske kriteriji identični kriterijima iz relevantne i recentne znanstvene literature:

- Jedno vozilo je sudjelovalo u PN (u pet od šest analiziranih PN).

- Vozač je bio sam u vozilu (u šest od šest analiziranih PN).

- Vozilo je sletjelo s ceste (u pet od šest analiziranih PN) ili je udarilo u objekt na/pored ceste (u jednoj od šest analiziranih PN).

- $\mathrm{PN}$ se desila na cesti s visokim ograničenjem brzine (u pet od šest analiziranih PN).

- PN događaju se rano ujutro, u poslijepodnevnim satima ili kasno navečer (u pet od šest analiziranih PN).

- Prometni okoliš lokacije PN je iznimno monoton (u šest od šest analiziranih PN).

- Posljedice PN su teške ozljede ili poginuli (1 poginuli vozač, 5 teško ozlijeđenih vozača i 1 vozač bez ozljeda, sve navedeno od sedam vozača sudionika u šest analiziranih $\mathrm{PN}$ ).

- Povećani rizik od vožnje u pospanom stanju vozača mlađih od 30 godina (tri od sedam vozača sudionika u šest PN su mlađi od 30 godina). 


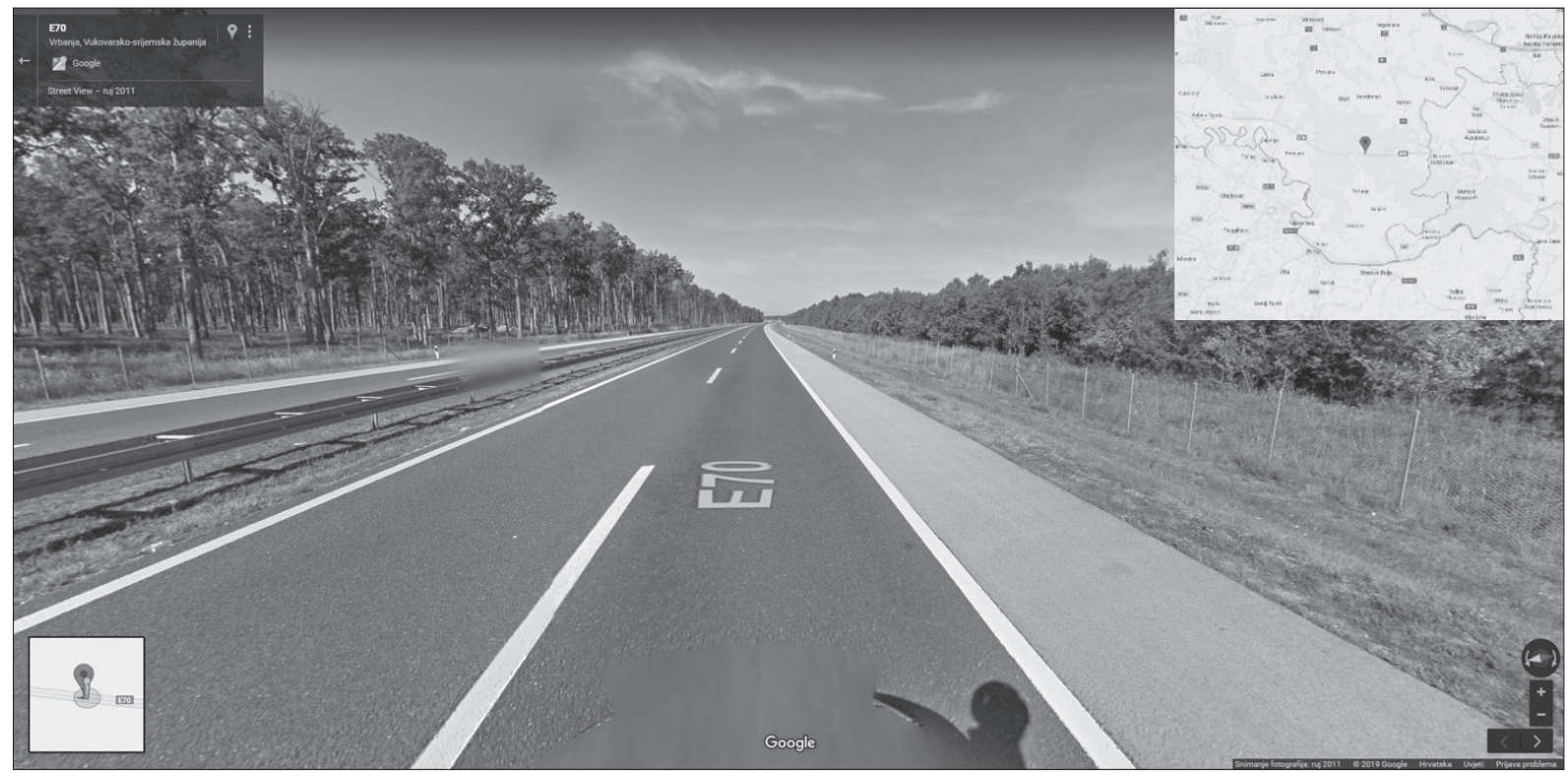

Slika 3. Lokacija PN 19434 na AC A3

Figure 3. Location of the 19434 accident on A3 motorway

Tablica 9. Ocjena sigurnosti iRAP metodologijom za lokaciju PN prikazanu na slici 3

Table 9. Safety assessment using iRAP methodology for the location shown in figure 3

\begin{tabular}{||l|c|c|c|c||}
\hline \multicolumn{5}{|c||}{ Ocjenjivanje zvjezdicama postojećih prometnica (engl. Star Ratings for the existing road): } \\
\hline Korisnik ceste & Vozilo & Motocikl & Pješak & Biciklist \\
\hline SRS ocjena & 9,67 & 25,12 & NA & NA \\
\hline Ocjene zvjezdicama (engl. Star Rating) & 3 & 1 & NA & NA \\
\hline
\end{tabular}

Tablica 10. Analiza elemenata PN za lokaciju PN prikazanu na slici 3

Table 10. Analysis of the accident elements for the location in figure 3

\begin{tabular}{|l|c|l|c||}
\hline \multicolumn{1}{|c|}{ Cesta } & AC 3 & \multicolumn{1}{c|}{ PN } & 19434 \\
\hline Datum i godina & 24.7 .2013$. & GPS koordinate & $45^{\circ} 02^{\prime} 42.7^{\prime \prime} \mathrm{N}, 18^{\circ} 56^{\prime} 18.0^{\prime \prime} \mathrm{E}$ \\
\hline Okoliš prometnice & monoton & Vrijeme & $01: 50$ \\
\hline Umor prema MUP-u RH (DA/NE) & DA & Vrsta PN & (8) - slijetanje vozila s ceste \\
\hline Okolnosti & $(19)-$ ostale greške vozača & Sudjelovalo vozila & 1 \\
\hline Karakteristike ceste & $(18)-$ ravni cestovni potez & Stanje kolničke površine & $(1)-$ suh-čist \\
\hline Ograničenje brzine (km/h) & 130 & Vidljivost & noć \\
\hline Muških vozača & 1 & Ženskih vozača & 0 \\
\hline Navršena dob vozača (god.) & 73,34 god. & Posljedice PN & teško ozlijeđen \\
\hline Procjena suradnika iz MUP-a RH & \multicolumn{2}{|c|}{ Konstatirano spavanje, vjerojatnost umora 100 \% } \\
\hline
\end{tabular}




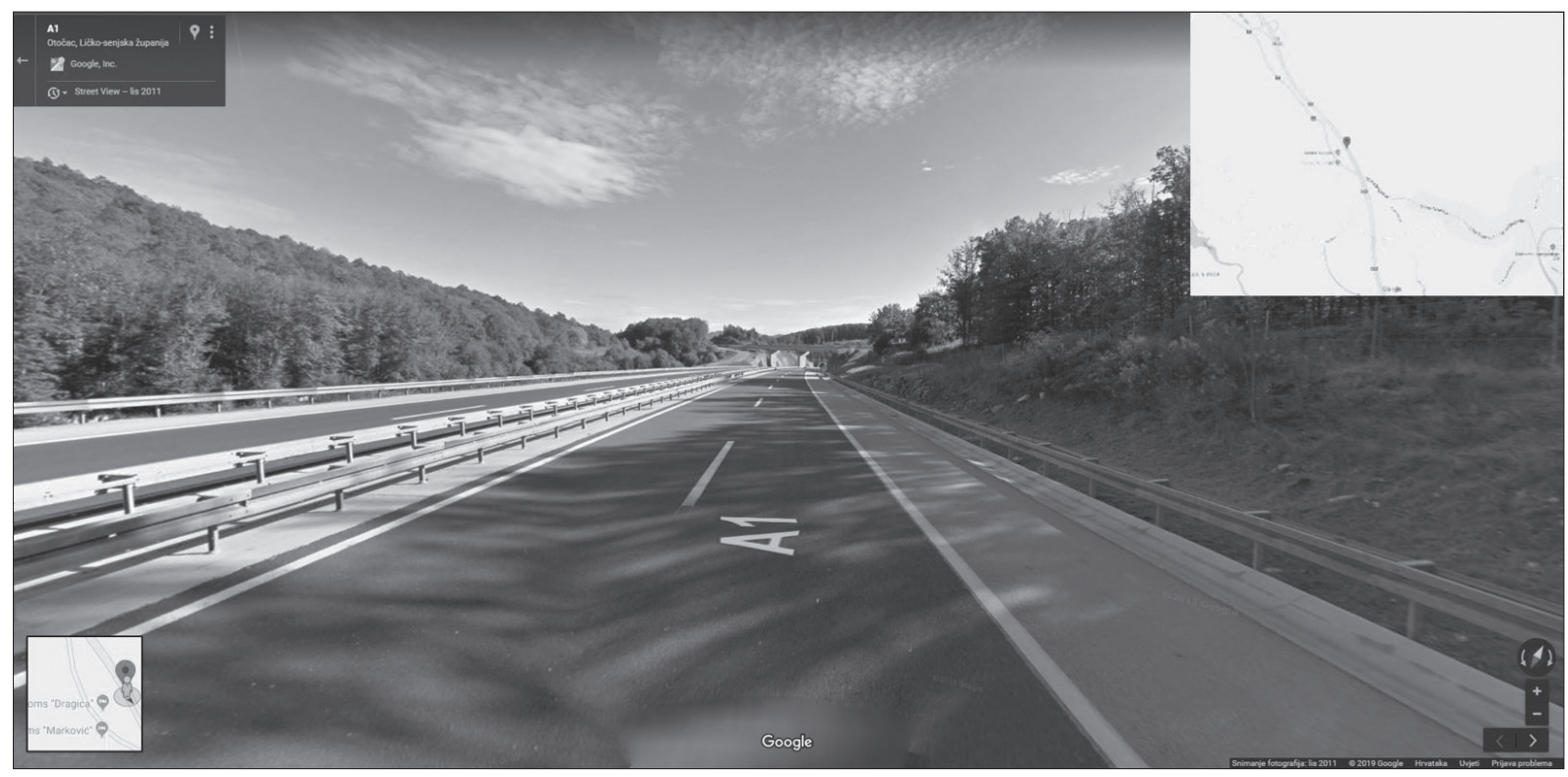

Slika 4. Lokacija PN 22316 na AC A1

Figure 4. Location of the 22316 accident on A1 motorway

Tablica 11. Ocjena sigurnosti iRAP metodologijom za lokaciju PN prikazanu na slici 4

Table 11. Safety assessment using iRAP methodology for the location shown in figure 4

\begin{tabular}{||l|c|c|c|c||}
\hline \multicolumn{5}{|c||}{ Ocjenjivanje zvjezdicama postojećih prometnica (engl. Star Ratings for the existing road): } \\
\hline Korisnik ceste & Vozilo & Motocikl & Pješak & Biciklist \\
\hline SRS ocjena & 6,91 & 23,79 & NA & NA \\
\hline Ocjene zvjezdicama (engl. Star Rating) & 3 & 1 & NA & NA \\
\hline
\end{tabular}

Tablica 12. Analiza elemenata PN za lokaciju PN prikazanu na slici 4

Table 12. Analysis of the accident elements for the location in figure 4

\begin{tabular}{|l|c|c|c||}
\hline \multicolumn{1}{|c|}{ Cesta } & AC 1 & PN & 22316 \\
\hline Datum i godina & 26.8 .2016$. & GPS koordinate & $44^{\circ} 52.735,15^{\circ} 12.232$ \\
\hline Okoliš prometnice & monoton & Vrijeme & $02: 42$ \\
\hline Umor prema MUP-u RH (DA/NE) & DA & Vrsta PN & (8) - slijetanje vozila s ceste \\
\hline Okolnosti & $(19)-$ ostale greške vozača & Sudjelovalo vozila & 1 \\
\hline Karakteristike ceste & $(18)-$ ravni cestovni potez & Stanje kolničke površine & $(1)-$ suh-čist \\
\hline Ograničenje brzine $(\mathbf{k m} / \mathbf{h})$ & 130 & Vidljivost & $(2)-$ noć \\
\hline Muških vozača & 1 & Ženskih vozača & 0 \\
\hline Navršena dob vozača (god.) & 51,96 & Posljedice PN & teško ozlijeđen \\
\hline Procjena suradnika iz MUP-a RH & & Utvrđen umor & \\
\hline
\end{tabular}




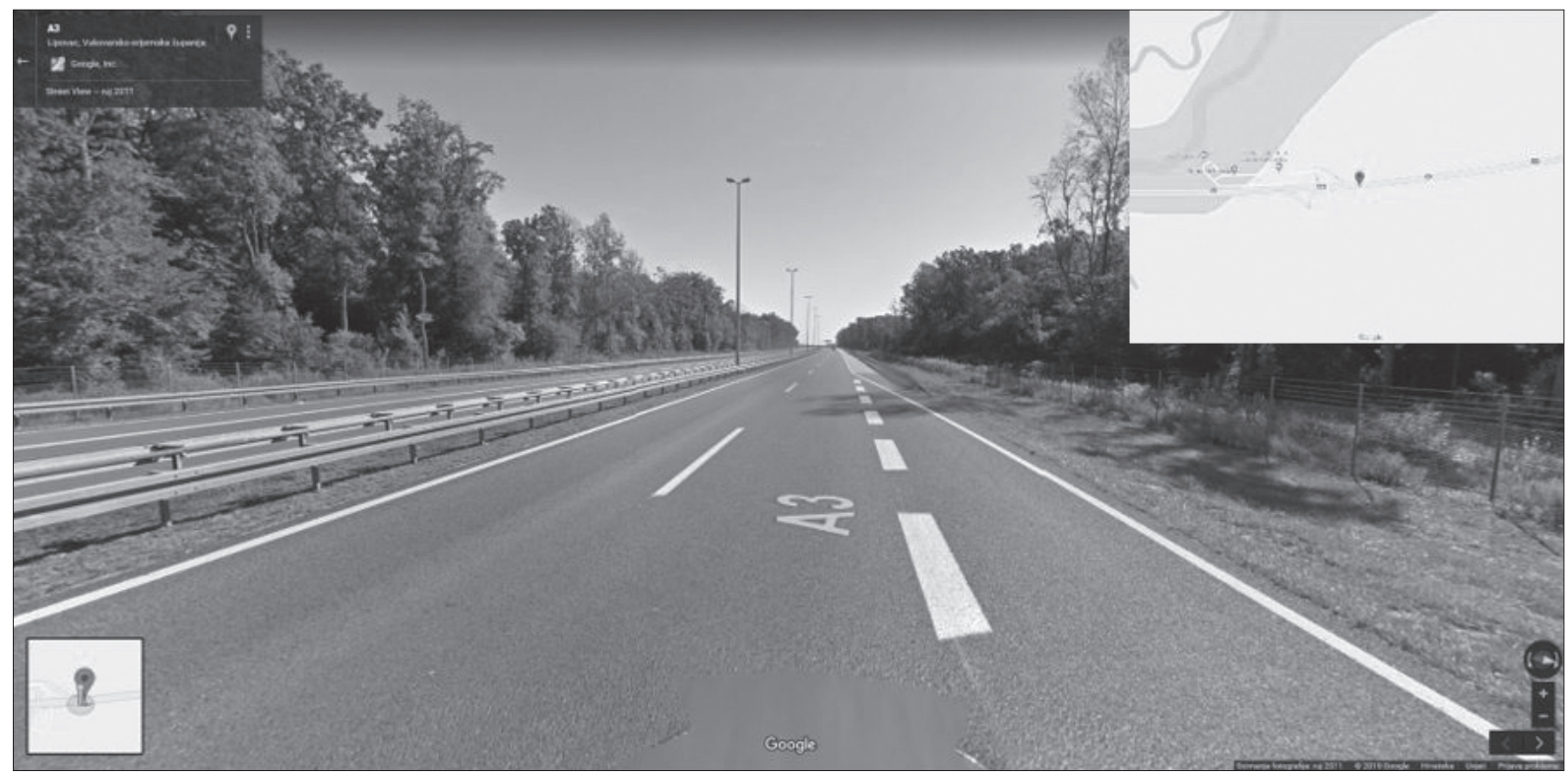

Slika 5. Lokacija PN 12568 na AC A3

Figure 5. Location of the 12568 accident on A3 motorway

Tablica 13. Ocjena sigurnosti iRAP metodologijom za lokaciju PN prikazanu na slici 5

Table 13. Safety assessment using iRAP methodology for the location shown in figure 5

\begin{tabular}{||l|c|c|c|c||}
\hline \multicolumn{5}{|c||}{ Ocjenjivanje zvjezdicama postojećih prometnica (engl. Star Ratings for the existing road): } \\
\hline Korisnik ceste & Vozilo & Motocikl & Pješak & Biciklist \\
\hline SRS ocjena & 7,74 & 20,11 & NA & NA \\
\hline Ocjene zvjezdicama (engl. Star Rating) & 3 & 2 & NA & NA \\
\hline
\end{tabular}

Tablica 14. Analiza elemenata PN za lokaciju PN prikazanu na slici 5

Table 14. Analysis of the accident elements for the location shown in figure 5

\begin{tabular}{|c|c|c|c|}
\hline Cesta & AC 3 & PN & 12568 \\
\hline Datum i godina & 31.5 .2017 & GPS koordinate & $45^{\circ} 02.693,19^{\circ} 00.337$ \\
\hline Okoliš prometnice & monoton & Vrijeme & 02:00 \\
\hline Umor prema MUP-u RH (DA/NE) & NE & Vrsta PN & $\begin{array}{l}\text { (16) - udar vozila u objekt } \\
\text { kraj ceste }\end{array}$ \\
\hline Okolnosti & (19) - ostale greške vozača & Sudjelovalo vozila & 1 \\
\hline Karakteristike ceste & (18) - ravni cestovni potez & Stanje kolničke površine & (1) - suh-čist \\
\hline Ograničenje brzine $(\mathrm{km} / \mathrm{h})$ & 130 & Vidljivost & (2) - noć \\
\hline Muških vozača & 1 & Ženskih vozača & 0 \\
\hline Navršena dob vozača (god.) & 62,77 & Posljedice PN & teško ozlijeđen \\
\hline Procjena suradnika iz MUP-a RH & & Sigurno umor & \\
\hline
\end{tabular}




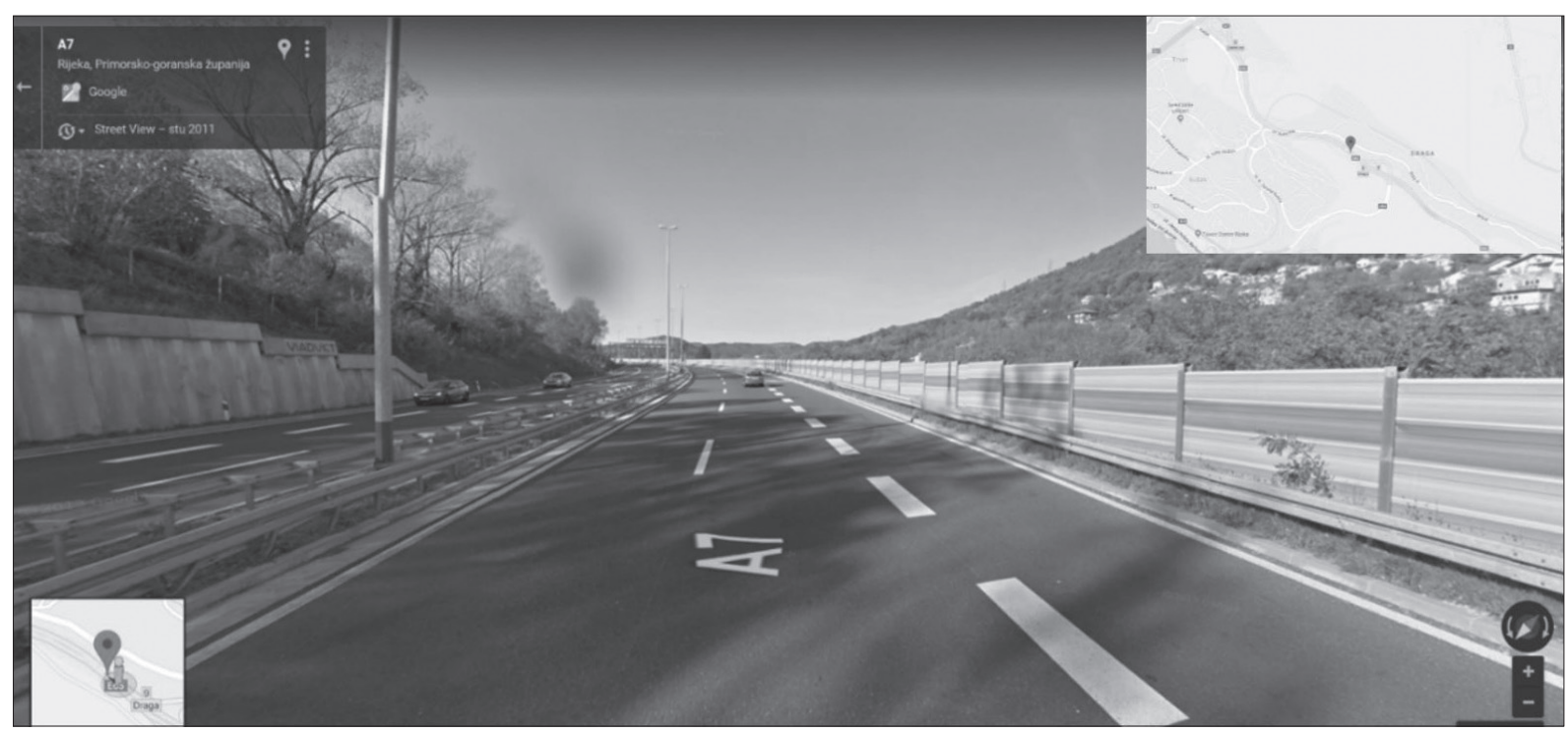

Slika 6. Lokacija PN 34870 na AC A7

Figure 6. Location of the 34870 accident on A7 motorway

Tablica 15. Ocjena sigurnosti iRAP metodologijom za lokaciju PN prikazanu na slici 6

Table 15. Safety assessment using iRAP methodology for the location shown in figure 6

\begin{tabular}{||l|c|c|c|c||}
\hline \multicolumn{4}{|c||}{ Ocjenjivanje zvjezdicama postojećih prometnica (engl. Star Ratings for the existing road): } \\
\hline Korisnik ceste & Vozilo & Motocikl & Pješak & Biciklist \\
\hline SRS ocjena & 2,59 & 8,64 & NA & NA \\
\hline Ocjene zvjezdicama (engl. Star Rating) & 4 & 3 & NA & NA \\
\hline
\end{tabular}

Tablica 16. Analiza elemenata PN za lokaciju PN prikazanu na slici 6

Table 16. Analysis of the accident elements for the location shown in figure 6

\begin{tabular}{|c|c|c|c|}
\hline Cesta & AC 7 & PN & 34870 \\
\hline Datum i godina & 21.12.2013. & GPS koordinate & $45^{\circ} 19^{\prime} 31.1^{\prime \prime} \mathrm{N}, 14^{\circ} 29^{\prime} 15.0^{\prime \prime} \mathrm{E}$ \\
\hline Okoliš prometnice & monoton & Vrijeme & $1: 50$ \\
\hline Umor prema MUP-u RH (DA/NE) & NE & Vrsta PN & (8) - slijetanje vozila s ceste \\
\hline Okolnosti & $\begin{array}{l}\text { (20) - nepropisno kretanje } \\
\text { vozila na kolniku }\end{array}$ & Sudjelovalo vozila & 1 \\
\hline Karakteristike ceste & $(17)-$ zavoj & Stanje kolničke površine & (2) - mokar \\
\hline Ograničenje brzine (km/h) & 80 & Vidljivost & (2) - noć \\
\hline Muških vozača & 1 & Ženskih vozača & 0 \\
\hline Navršena dob vozača (god.) & 61,76 & Posljedice PN & teško ozlijeđen \\
\hline Procjena suradnika iz MUP-a RH & & Sigurno umor & \\
\hline
\end{tabular}




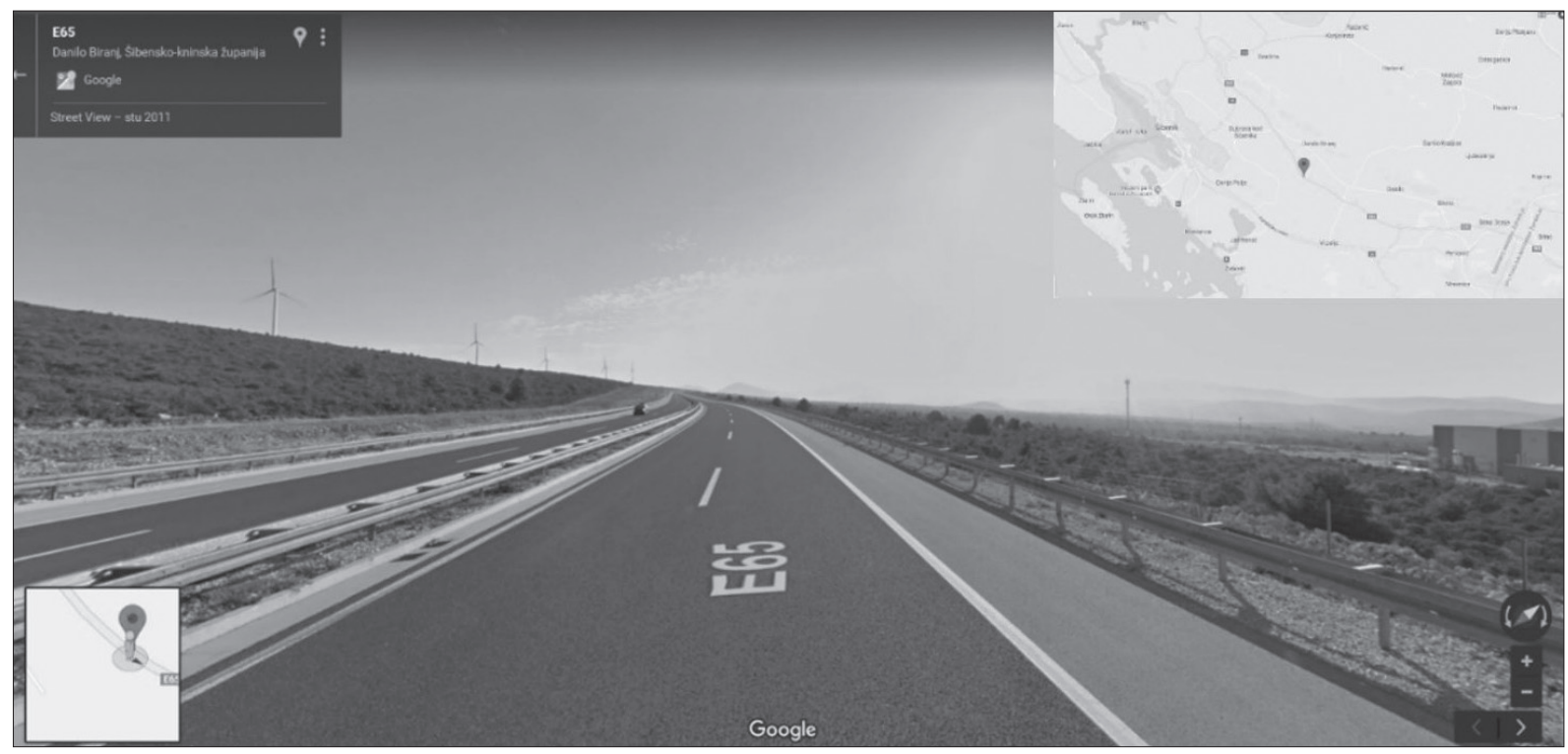

Slika 7. Lokacija PN 17082 na AC A1

Figure 7. Location of the 17082 accident on A1 motorway

Tablica 17. Ocjena sigurnosti iRAP metodologijom za lokaciju PN prikazanu na slici 7

Table 17. Safety assessment using iRAP methodology for the location shown in figure 7

\begin{tabular}{||l|c|c|c|c||}
\hline \multicolumn{4}{|c|}{ Ocjenjivanje zvjezdicama postojećih prometnica (engl. Star Ratings for the existing road): } \\
\hline Korisnik ceste & Vozilo & Motocikl & Pješak & Biciklist \\
\hline SRS ocjena & 6,91 & 23,79 & NA & NA \\
\hline Ocjene zvjezdicama (engl. Star Rating) & 3 & 1 & NA & NA \\
\hline \hline
\end{tabular}

Tablica 18. Analiza elemenata PN za lokaciju PN prikazanu na slici 7

Table 18. Analysis of the accident elements for the location shown in figure 7

\begin{tabular}{|l|c|l|c||}
\hline \multicolumn{1}{|c|}{ Cesta } & \multicolumn{1}{|c|}{ AC 1 } & \multicolumn{1}{c||}{17082} \\
\hline Datum i godina & 21.7 .2014$. & GPS koordinate & $43^{\circ} 42^{\prime} 32.8^{\prime \prime} \mathrm{N}, 15^{\circ} 59^{\prime} 35.7^{\prime \prime} \mathrm{E}$ \\
\hline Okoliš prometnice & monoton & Vrijeme & $3: 00$ \\
\hline Umor prema MUP-u RH (DA/NE) & NE & Vrsta PN & $(8)-$ slijetanje vozila s ceste \\
\hline Okolnosti & $\begin{array}{c}(20)-\text { nepropisno kretanje } \\
\text { vozila na kolniku }\end{array}$ & Sudjelovalo vozila & 1 \\
\hline Karakteristike ceste & $(17)-$ zavoj & Stanje kolničke površine & $(1)-$ suh - čist \\
\hline Ograničenje brzine (km/h) & 130 & Vidljivost & $(2)-$ noć \\
\hline Muških vozača & 1 & Ženskih vozača & 0 \\
\hline Navršena dob vozača (god.) & 18,3 & Posljedice PN & teško ozlijeđen \\
\hline Procjena suradnika iz MUP-a RH & & \multicolumn{1}{c|}{ Sigurno umor } & \\
\hline \hline
\end{tabular}




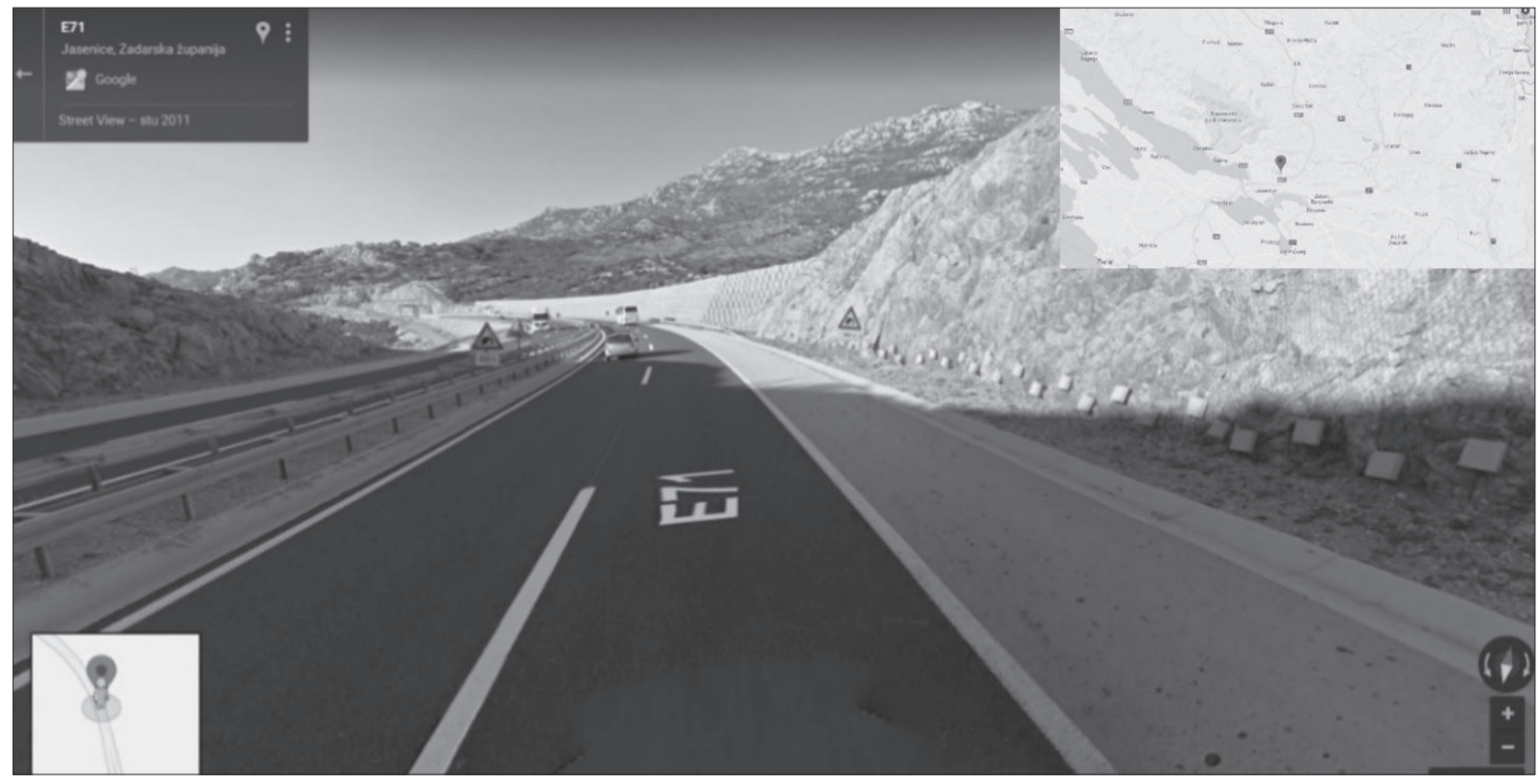

Slika 8. Lokacija PN 1462 na AC A1

Figure 8. Location of the 1462 accident on A1 motorway

Tablica 19. Ocjena sigurnosti iRAP metodologijom za lokaciju PN prikazanu na slici 8

Table 19. Safety assessment using iRAP methodology for the location shown in figure 8

\begin{tabular}{||l|c|c|c|c||}
\hline \multicolumn{4}{|c||}{ Ocjenjivanje zvjezdicama postojećih prometnica (engl. Star Ratings for the existing road): } \\
\hline Korisnik ceste & Vozilo & Motocikl & Pješak & Biciklist \\
\hline SRS ocjena & 6,33 & 11,96 & NA & NA \\
\hline Ocjene zvjezdicama (engl. Star Rating) & 3 & 3 & NA & NA \\
\hline
\end{tabular}

Tablica 20. Analiza elemenata PN uz procjenu suradnika iz MUP-a RH za lokaciju PN prikazanu na slici 8

Table 20. Analysis of the accident elements with the police assessment for the location in figure 8

\begin{tabular}{|l|c|c|c||}
\hline \multicolumn{1}{|c|}{ Cesta } & AC 1 & PN & 1462 \\
\hline Datum i godina & 12.1 .2016$. & GPS koordinate & $44^{\circ} 15^{\prime} 23.0^{\prime \prime} \mathrm{N}, 15^{\circ} 36^{\prime} 21.0^{\prime \prime} \mathrm{E}$ \\
\hline Okoliš prometnice & monoton & Vrijeme & $18: 39$ \\
\hline Umor prema MUP-u RH (DA/NE) & NE & Vrsta PN & $(8)$ - slijetanje vozila s ceste \\
\hline Okolnosti & $(19)-$ ostale greške vozača & Sudjelovalo vozila & 2 \\
\hline Karakteristike ceste & $(17)-$ zavoj & Stanje kolničke površine & $(1)-$ suh - čist \\
\hline Ograničenje brzine (km/h) & 100 & Vidljivost & $(2)-$ noć \\
\hline Muških vozača & 2 & Ženskih vozača & 0 \\
\hline Navršena dob vozača (god.) & $18,72 / 24,12$ & Posljedice PN & poginuo / bez ozljeda \\
\hline Procjena suradnika iz MUP-a RH & & Vjerojatno umor & \\
\hline
\end{tabular}




\section{RASPRAVA}

Svih 6 lokacija analiziranih PN na $\mathrm{AC}$ u $\mathrm{RH}$ ocijenjene su visoko rangiranom ocjenom za statičku sigurnost (u rasponu od 3 do 4 zvjezdice od 5 mogućih zvjezdica). Generalno razmatrajući, prometna infrastruktura od 6 analiziranih lokacija PN nije bila dominantni uzrok njihova nastanka, jer se zbog visokih ocjena prema iRAP metodologiji čimbenici prometne infrastrukture iz skupine čimbenika "prometni okoliš" mogu potpuno isključiti kao uzrok nastanka istraživanih PN. Zbog navedenog i uz pretpostavku tehničke ispravnosti vozila koja su sudjelovala u istraživanim PN (sva vozila koja su sudjelovala u PN prošla su tehničke preglede i registraciju) mogući glavni uzrok za nastanak u radu istraživanih PN potrebno je tražiti među čimbenicima "ljudskog faktora", čemu je vjerojatno znatno pridonio i umor. To dodatno potvrđuje i osobna procjena o umoru kao mogućem uzroku PN od strane iskusnog suradnika iz MUP-a RH na temelju uvida u kompletnu dokumentaciju o PN.

Ocjena u formi zvjezdica je objektivna mjera statističkog rizika i vjerojatnosti nastanka PN i težine njezinih posljedica. Fokus ocjenjivanja prometne infrastrukture iRAP metodologijom je na identificiranju i evidentiranju atributa ceste koji utječu na najčešće vrste PN i PN s najtežim posljedicama, na temelju znanstvenih istraživanja utemeljenih na dokazima o statističkom riziku. Rezultati međunarodnih istraživanja i ekspertiza statističkog rizika PN u cijelome svijetu koji su implementirani u iRAP metodologiju pokazuju da je statistički rizik od smrti i ozbiljnih ozljeda najviši na cestama s jednom zvjezdicom, a najmanji na cesti s pet zvjezdica. Ceste s tri i više zvjezdica za sve sudionike u cestovnom prometu su ključ za spašavanje ljudskih života i prevencije teških ozljeda. Na taj način može se definirati stupanj rizika korisnika ceste na određenoj mreži bez potrebe za detaljnim podacima iz očevida o PN i dubinskim analizama čimbenika PN (https://vida. irap.org/en-gb/home).

U studijama umora uporaba simulatora vožnje široko je prihvaćena posljednjih nekoliko godina (Ting et al., 2008., Philip et el., 2005., Thiffault, Bergeron, 2003.). Rezultati komparativnih analiza čimbenika PN na AC za koje je mogući uzrok i umor vozača s recentnim spoznajama iz literature će se uvažavati tijekom dizajniranja scenarija vožnje na AC za simulator cestovnog prometa, a na način da se sve relevantne okolnosti koje mogu izazvati umor vozača implementiraju u scenarij. Planirana mjerenja izvedbe u simulatoru cestovnog prometa u okolnostima pojave umora vozača u nastavku istraživanja omogućiti će dodatne analize rizičnih čimbenika pojave umora tijekom vožnje u sigurnom i kontroliranom okruženju koje će biti gotovo identično realnim okolnostima pojave umora kod vozača cestovnih vozila.

U dubinskim analizama lokacija šest karakterističnih PN pomoću iRAP metodologije u ovome radu uvažena su dva od tri najvažnija čimbenika pojave pasivnog umora kao uzroka nastanka PN u studiji iz 2011. godine (Rossi et al., 2011.): monotoni okoliš prometnice (u šest od šest analiziranih PN) i mogući utjecaj cirkadijurnih ritmova na izvedbu vozača cestovnih vozila (pet od šest analiziranih PN dogodio se između 1:50 i 3:00 h u jutarnjim satima).

\section{ZAKLJUČAK}

U radu je potvrđena hipoteza kako se procjenom statičke sigurnosti prometne infrastrukture pomoću iRAP metodologije čimbenici prometne infrastrukture iz skupine čimbenika „prometni okoliš" mogu u cijelosti isključiti kao uzrok nastanka šest u radu istraživanih PN kojima je vjerojatni uzrok umor, uz pretpostavku tehničke ispravnosti vozila jer su sva vozila koja su sudjelovala u PN prošla tehnički pregled i registraciju. Zbog navedenog, glavni uzrok za nastanak u radu šest analiziranih karakterističnih PN na AC potrebno je tražiti među čimbenicima "ljudskog faktora" te se umor vozača cestovnog vozila može prihvatiti kao najvjerojatniji čimbenik njihova nastanka, jer su se tijekom selekcije i analiza šest karakterističnih PN na AC u RH uvažavali relevantni kriteriji iz recentne znanstvene literature koji upućuju na umor kao mogući uzrok nastanka PN.

$\cup$ radu je također ukazano na nužnost ozbiljnijeg pristupa prikupljanju relevantnih podataka o PN tijekom njihova očevida, kao i na nužnost popunjavanja i održavanja baze PN podacima o PN od strane motiviranih i dobro educiranih djelatni- 
ka MUP-a RH, jer bez profesionalnog pristupa prikupljanju relevantnih podataka o čimbenicima PN nije moguće statističkim metodama dobiti vjerodostojne rezultate o utjecaju pojedinih čimbenika na događanje $\mathrm{PN}$ te nije moguće odrediti postotni udjel PN na AC u RH povezivih s umorom vozača.

Ozbiljni nedostaci baze PN u RH formirane i održavane od strane djelatnika MUP-a RH koji u znatnoj mjeri narušavaju pouzdanost $\mathrm{i}$ vjerodostojnost dobivenih rezultata - ako se zaključci temelje samo na statističkim obradama podataka o PN iz iste baze - jesu ovi: GPS koordinate za pojedine PN krivo su očitane i/ili su krivo unesene u bazu o PN, u bazi koja se odnosi na poginule i teško ozlijeđene sudionike u PN nedostaje do $5 \%$ vrijednosti pojedinih varijabli, tj. čimbenika PN, dok u bazama za lakše ozlijeđene i s materijalnom štetom taj postotak vrijednosti pojedinih varijabli koje nedostaju kreće se u postotnom udjelu od čak 10 do $15 \%$.

\section{LITERATURA}

Connor, J., Norton, R., Ameratunga, S., Robinson, E., Wigmore, B. \& Jackson, R.: Prevalence of driver sleepiness in a random population-based sample of car driving. Sleep, 24, 2001.a, 6, pp. 688-694.

Connor, J. L., Whitlock, G., Norton, R., Jackson, R.: The role of driver sleepiness in car crashes: a systematic review of epidemiological studies, Accident Analysis \& Prevention, svez. 33, 2001.b, br. 1, pp. 33-41.

Društvo automobilskih inženjera SAE: Povijest, dostupno na: https://www.sae.org/about/history, pristupljeno: 16.6.2019.

Društvo automobilskih inženjera SAE: Automatizirana vožnja: Razine automatizacije vožnje prema SAE Internacionalnom standardu J3016, dostupno na: https://www.sae.org/misc/pdfs/automated_driving.pdf, pristupljeno: 10.4.2019.

Fuller, R.: Towards a general theory of driver behaviour, Accident Analysis and Prevention, 37, 2005., Issue 3, pp. 461-472.

GMaps. Google, Google maps, 2019. dostupno na: https://maps.google.hr/, pristupljeno: 22.4.2019.
Halvani, G. H., Ebrahemzadih, M., Esmaeili, A.: Sleepiness and accidents among professional drivers, Safety: Journal for the safety in the work organization and living environment, 61, 2019., 1, pp. 15-25.

Horne, J. and Reyner, L.: Vehicle accidents related to sleep: a review. Occup Environ Med, 56, 1999., 5, pp. 289-294.

iRAP: How we Can Help, dostupno na: https:// www.irap.org/how-we-can-help/, pristupljeno 14.5.2019.

IRAP: The International Road Assessment Programme (iRAP), dostupno na: https://vida.irap. org/en-gb/home, pristupljeno: 12.4.2019.

Julie, H., Ralston, F.: The role of risk-propensity in the risky driving of younger drivers. Accident Analysis and Prevention. 41, 2009., 1, pp. 25-35.

Kroemer, K. H., Grandjean, E.: Prilagođavanje rada čovjeku. Naklada Slap, Jastrebarsko, 2000. (Original: Kroemer, K.H.E.; Grandjean, E. 1997. Fitting the Task to the Human. A Textbook of Occupational Ergonomics. Fifth Edition. Taylor \& Francis. London.)

Lela, R.W., David, R.D., Kris, T., Judith R.D., Alistair, W.M.: Young drivers' perceptions of culpability of sleep-deprived versus drinking drivers. Journal of Safety Research. 43, 2012., 2, pp. 115122.

Lyznicki, J. M., Doege, T. C., Davis, R. M. and Williams, M. A.: Sleepiness, driving and motor vehicle crashes, Journal of the American Medical Association, 279, 1998., 23, pp. 1908-1913.

Maycock, G.: Sleepiness and driving and experience of U.K. car drivers, Accident Analysis and prevention, 29, 1997., 4, pp. 453-462.

Philip, P., Sagaspe, P., Taillard, S., Valtat, C., Moore, N., Akerstedt, T.: Fatigue, Sleepiness and Performance in Simulated VersusReal Driving Conditions. Sleep, 28, 2005., 12, pp. 1511-1516.

Prema nultoj osnovi: Sigurnosni sustav, dostupno na: http://www.towardszerofoundation.org/ thesafesystem/, pristupljeno: 15.5.2019.

Pribyl, O., Koukol, M., Kuklova, J.: Computational intelligence in highway management: A 
review. Promet - Traffic \& Transportation. 28, 2015., 3, pp. 439-450.

Rossi, R., Gastaldi, M., Gecchele, G.: Analysis of driver task-related fatigue using driving simulator experiments, Procedia - Social and Behavioral Sciences, 20, 2011., pp. 666675.

Rumar, K.: The human factors in road safety, XI ARRB Conference, Australian Road Research Board Proceedings, vol. 11, 1982., Part 1, Melbourne, pp. 65-78.
Thiffault, P. \& Bergeron, J.: Monotony of road environment and driver fatigue: a simulator study. Accident Analysis and Prevention, 35, 2003., 3, pp. 381-391.

Ting, P.H., Hwang, J.R., Doong, J.L. \& Jeng, M.C.: Driver fatigue and highway driving: A simulator study. Physiology \& Behavior, 94, 2008., 3, pp. 448-453.

van der Hulst, M., Meijman, T. and Rothengatter, T.: Maintaining task set under fatigue: a study of time-on-task effects in simulated driving, Transportation Research Part F, 4, 2001., 2, pp. 103-118.

\title{
USING IRAP METHODOLOGY WHEN SELECTING TRAFFIC ACCIDENTS CAUSED BY ROAD VEHICLES DRIVER FATIGUE
}

\begin{abstract}
SUMMARY: Using only classical methods based on the calculation of objective statistical risk after the traffic accident expertise, it is very difficult to select the traffic accidents that were probably caused by fatigue of road vehicle drivers. The iRAP methodology can significantly assist in the selection of road traffic accidents which were probably caused by the driver's fatigue, because by using the iRAP methodology the static safety of road infrastructure elements can be quickly and objectively evaluated, and then excluded as a possible cause of a traffic accident. According to dynamic and open TCI Fuller's model "task demand - driver's capability", drivers dominantly influence the desired level of task demand while driving by choosing the speed, which in the case of choosing the unacceptable speed or speed unsuited for the environmental conditions on the road, among the rest, may depend on whether the driver is under the influence of fatigue. On the example of six traffic accidents that occurred on motorways in the Republic of Croatia and were selected for statistical analysis by characteristic criteria from the recent scientific literature, it will be presented how by using the iRAP methodology the factors of road infrastructure from the group of "traffic environment" factors can be completely excluded as the cause of traffic accidents. The more accurate selection of road traffic accidents that were caused by driver's fatigue will help researchers from other scientific fields to select and explore the characteristic factors of fatigue-related traffic accidents in order to suggest measures to reduce the fatigue effect on the driver's performance.
\end{abstract}

Key words: fatigue, road traffic accidents, road vehicles, task demand, performance, safety

Preliminary communication Received: 2019-07-15

Accepted: 2020-03-08 